\title{
Aluminium bone disease in patients receiving plasma exchange with contaminated albumin
}

\author{
D MAHARAJ, G S FELL, B F BOYCE, J P NG, G D SMITH, J M BOULTON-JONES, \\ R L C CUMMING, J F DAVIDSON
}

\begin{abstract}
Aluminium balance studies were carried out on eight patients with various immunological disorders who were receiving plasma exchange with albumin solutions known to be contaminated with aluminium. Four patients with impaired renal function (creatinine clearance $<50 \mathrm{ml} / \mathrm{min}$ ) retained between $60 \%$ and $74 \%$ of the aluminium infused during a single plasma exchange. Transiliac bone biopsy specimens from three patients in this group had a high content of aluminium and showed histological evidence of current or previous bone disease related to aluminium. Two of these patients suffered intermittent bone pain. The main route of excretion of injected aluminium was in urine, only a small proportion of the total input being removed in the "plasma bag" during plasma exchange. The extent of aluminium retention and bone deposition was not reflected by the plasma aluminium concentration before or after plasma exchange. Treatment of five patients with intravenous desferrioxamine increased the plasma aluminium concentration and urinary output of aluminium in those with evidence of aluminium retention.

These studies show that patients with poor renal function
\end{abstract} receiving treatment with albumin contaminated with aluminium

Department of Haematology, Memorial Hospital, Darlington DL3 6HX

D MAHARAJ, MRCP, MRCPATH, consultant haematologist

Departments of Pathological Biochemistry, Pathology, Renal Medicine, and Haematology, Royal Infirmary, Glasgow G4 OSF

G S FELL, PHD, FRCPATH, reader in pathological biochemistry

B F BOYCE, MB, MRCPATH, senior lecturer in pathology

J M BOULTON-JONES, MB, FRCP, consultant physician

J F DAVIDSON, FRCP, FRCPATH, consultant haematologist

Departments of Pathology and Haematology, Stobhill Hospital, Glasgow G21 3UW

J P NG, MB, MRCP, registrar in haematology

G D SMITH, MB, MRCPATH, consultant pathologist

R L C CUMMING, MD, FRCP, consultant haematologist

Correspondence to: Dr Maharaj or Dr Fell. retain the metal and deposit it in bone, where it may eventually cause aluminium bone disease. Plasma exchange should be used with caution in patients with renal impairment.

\section{Introduction}

Albumin solutions are contaminated with various trace metals, including aluminium..$^{1-3}$ On repeated analysis of 10 different batches of two commercial preparations of human albumin we found that stable plasma protein solution (4.3\%) manufactured at the Scottish National Blood Transfusion Service, Edinburgh, contained an average of $18.3 \mu \mathrm{mol}$ aluminium/l (SD $2 \mu \mathrm{mol} / \mathrm{l} ; \mathrm{n}=70$ ) and that human albumin (4.3\%) manufactured by Immuno AG, Vienna, contained an average of $9.1 \mu \mathrm{mol}$ aluminium/1 (SD $0.6 \mu \mathrm{mol} / \mathrm{l}$; $\mathbf{n}=80$ ). Given that the concentration of aluminium in human plasma is normally less than $0.5 \mu \mathrm{mol} / \mathrm{l}$, infusion of these solutions provides an important source of excess aluminium, with the consequent risk of toxicity.

Albumin solutions are widely used to expand the intravascular volume in patients with acute hypovolaemic states. It is also common to use an albumin solution as the replacement fluid during plasma exchange, and this procedure has been proposed as an effective treatment for various disorders, some of which may be associated with renal insufficiency. ${ }^{45}$

In patients with chronic renal failure aluminium has been implicated in the pathogenesis of vitamin D resistant osteomalacia (often with hypercalcaemia). ${ }^{6}$ Microcytic anaemia and dialysis encephalopathy are other recognised toxic effects. ${ }^{7}$ Sources of aluminium include dialysate fluid, aluminium based phosphate binding drugs, and solutions for parenteral nutrition. This paper examines whether use of contaminated albumin as the replacement fluid in plasma exchange results in aluminium retention and aluminium related osteodystrophy in patients with impaired renal function.

\section{Patients and methods}

We studied five men and three women aged 21-74 who had been receiving regular plasma exchange for two months to seven years (table I). Two 
patients had mesangiocapillary glomerulonephritis and one IgA nephropathy. Three others had Waldenström's macroglobulinaemia, one had Guillain-Barré syndrome, and one myasthenia gravis. Two patients (cases 1 and 3) had suffered intermittent bone pain while receiving regular plasma exchange. The total load of aluminium received intravenously by the eight patients since beginning treatment ranged from 270 to $5700 \mu \mathrm{mol}$ (about 7-150 mg; table I). The input of aluminium was calculated by using the average aluminium concentration found for each type of albumin used for the plasma exchanges and the total volume of the solutions given.

Plasma exchange regimen-On each occasion 2.81 albumin solution was exchanged. Four patients (cases $1-4$ ) received $4 \cdot 3 \%$ human albumin (Immuno AG), the exchange being carried out with an IBM continuous flow cell separator, model 2997. The other four patients (cases 5-8) were treated with $4 \cdot 3 \%$ stable plasma protein solution (Scottish National Blood Transfusion Service) using a Fenwall continuous flow cell separator.

Metabolic balance study-During each plasma exchange samples of all replacement albumin infused and of all plasma removed from the patients were taken and the aluminium concentration determined. The patient's own plasma aluminium concentration was measured before and immediately after exchange. Twenty four hour urinary aluminium excretion was determined before and for three consecutive days after the procedure.

Bone biopsies-Four patients (cases 1, 2, 3, and 5) each had two bone biopsy specimens taken from the anterior iliac crest after double labelling with tetracycline. In the first specimen histomorphometric analysis of undecalcified sections was performed by published methods. ${ }^{6}$ The presence of aluminium in bone was shown by a staining procedure using aurine tricarboxylic acid (Aluminon). The bone aluminium content $(\mu \mathrm{g} / \mathrm{g}$ dry weight) was determined in the second specimen from each patient.

Desferrioxamine mobilisation test-Further to define the extent of aluminium retention a desferrioxamine infusion was given to five patients (cases 1, 2, 3, 5, and 6). ${ }^{8}$ Four grams desferrioxamine was infused in $250 \mathrm{ml}$ $5 \%$ dextrose over four hours. This was carried out at least two weeks after the last plasma exchange. Plasma aluminium concentrations were measured before and 48 hours after the infusion of desferrioxamine. The 24 hour excretion of aluminium in urine was measured before and for three consecutive days after the infusion.

Biochemistry-Aluminium concentrations in plasma, albumin solutions, urine, and bone were measured by carbon furnace atomic absorption spectrophotometry using adaptations of published methods. ${ }^{910}$

\section{Results}

Balance studies (table II)-Patients received an intravenous load of aluminium which varied from 11 to $123 \mu \mathrm{mol}$. Three patients (cases 1,2 , and 5) were each studied on two occasions, separated by one month. One of these patients (case 5) received a similar load of aluminium on each occasion, whereas the other two patients received different loads. The proportion of aluminium excreted in the urine, that removed during plasma exchange, and the overall retention were similar for each patient on the two occasions. The

TABLE I-Clinical details of patients having plasma exchange and calculated load of aluminium infused

\begin{tabular}{|c|c|c|c|c|c|c|}
\hline $\begin{array}{l}\text { Case } \\
\text { No }\end{array}$ & $\begin{array}{l}\text { Sex and age } \\
\text { (years) }\end{array}$ & Diagnosis & $\begin{array}{c}\text { Time on } \\
\text { plasma exchange }\end{array}$ & $\begin{array}{c}\text { Total No of } \\
\text { plasma exchanges }\end{array}$ & $\begin{array}{l}\text { Total volume of } \\
\text { albumin received (l) }\end{array}$ & $\begin{array}{l}\text { Calculated input of } \\
\text { aluminium ( } \mu \mathrm{mol})\end{array}$ \\
\hline $\begin{array}{l}1 \\
2 \\
3 \\
4 \\
5 \\
6 \\
7 \\
8\end{array}$ & $\begin{array}{l}\text { F } 23 \\
\text { M } 21 \\
\text { M 45 } \\
\text { F } 64 \\
\text { M } 52 \\
\text { M } 61 \\
\text { M } 74 \\
\text { F } 52\end{array}$ & $\begin{array}{l}\text { Mesangiocapillary glomerulonephritis } \\
\text { IgA Nephropathy } \\
\text { Mesangiocapillary glomerulonephritis } \\
\text { Waldenström's macroglobulinaemia } \\
\text { Waldenström's macroglobulinaemia } \\
\text { Myasthenia gravis } \\
\text { Waldenström's macroglobulinaemia } \\
\text { Guillain-Barré syndrome }\end{array}$ & $\begin{array}{l}4 \text { Years } 5 \text { months } \\
6 \text { Months } \\
7 \text { Years } \\
4 \text { Years } \\
2 \text { Years } 3 \text { months } \\
4 \text { Years } 6 \text { months } \\
2 \text { Years } \\
2 \text { Months }\end{array}$ & $\begin{array}{r}119 \\
29 \\
187 \\
12 \\
60 \\
11 \\
5 \\
5\end{array}$ & $\begin{array}{r}274 \\
82 \\
524 \\
32 \\
144 \\
31 \\
15 \\
15\end{array}$ & $\begin{array}{r}2983 \\
885 \\
5707 \\
291 \\
1570 \\
282 \\
275 \\
270\end{array}$ \\
\hline
\end{tabular}

TABLE II-Metabolic balance studies

\begin{tabular}{|c|c|c|c|c|c|}
\hline $\begin{array}{l}\text { Case } \\
\text { No }\end{array}$ & $\begin{array}{l}\text { Creatinine } \\
\text { clearance } \\
(\mathrm{ml} / \mathrm{min})\end{array}$ & $\begin{array}{c}\text { Aluminium infused } \\
\text { in albumin } \\
\text { ( } \mu \mathrm{mol})\end{array}$ & $\begin{array}{l}\text { Aluminium excreted } \\
\text { in urine over three days } \\
(\mu \mathrm{mol})\end{array}$ & $\begin{array}{l}\text { Aluminium removed } \\
\text { during plasma exchange } \\
(\mu \mathrm{mol})\end{array}$ & $\begin{array}{l}\text { Total amount of aluminium } \\
\text { retained as \% of infused } \\
\text { load }\end{array}$ \\
\hline $\begin{array}{l}1^{\star} \\
2^{\star} \\
3 \\
4 \\
5^{\star} \\
6 \\
7 \\
8\end{array}$ & $\begin{array}{r}\left\{\begin{array}{r}11 \\
10 \\
11 \\
10 \\
8\end{array}\right. \\
27 \\
\left\{\begin{array}{r}55 \\
51 \\
71\end{array}\right. \\
91 \\
121\end{array}$ & $\begin{array}{r}23.8 \\
36.4 \\
39 \cdot 2 \\
109 \cdot 0 \\
30.8 \\
11.0 \\
55.2 \\
54.0 \\
69.6 \\
123.0 \\
96.0\end{array}$ & $\begin{array}{r}5.0 \\
5.9 \\
5.3 \\
13.0 \\
3.5 \\
2.8 \\
28.1 \\
19.0 \\
59.2 \\
122.0 \\
85.0\end{array}$ & $\begin{array}{r}4 \cdot 4 \\
5 \cdot 4 \\
3.9 \\
15 \cdot 4 \\
5 \cdot 5 \\
0.9 \\
4 \cdot 2 \\
2.7 \\
7.9 \\
5 \cdot 3 \\
5 \cdot 3\end{array}$ & $\begin{array}{c}60 \cdot 6 \\
69 \cdot 0 \\
67 \cdot 5 \\
74 \cdot 0 \\
70 \cdot 6 \\
66 \cdot 0 \\
42 \cdot 0 \\
60 \cdot 0 \\
3 \cdot 6 \\
0 \\
6.5\end{array}$ \\
\hline
\end{tabular}

^Patient studied twice (interval one month).

TABLE III-Plasma aluminium concentrations before and immediately after plasma exchange

\begin{tabular}{cccc}
\hline $\begin{array}{c}\text { Case } \\
\text { No }\end{array}$ & $\begin{array}{c}\text { Plasma aluminium before } \\
\text { exchange } \\
(\mu \mathrm{mol} / 1)\end{array}$ & $\begin{array}{c}\text { Plasma aluminium after } \\
\text { exchange } \\
(\mu \mathrm{mol} / 1)\end{array}$ & $\begin{array}{c}\text { \% Retention of } \\
\text { aluminium }\end{array}$ \\
\hline & $\{0.6$ & 3.6 & 60.6 \\
$1^{\star}$ & $\{0.8$ & 2.4 & 69.0 \\
$2^{\star}$ & 30.8 & 2.2 & 67.5 \\
3 & 20.2 & 2.1 & 74.0 \\
4 & 2.1 & 2.7 & 70.6 \\
$5^{\star}$ & 0.4 & 1.1 & 66.0 \\
6 & 0.2 & 2.0 & 42.0 \\
7 & 0.1 & 2.1 & 60.0 \\
8 & 0.7 & 1.3 & 3.6 \\
& 0.2 & 1.9 & 0 \\
& 0.1 & 1.7 & 6.5 \\
\hline
\end{tabular}

^Patient studied twice (interval one month). total amount of aluminium retained by the patients was dependent on their renal function. Those with a creatinine clearance of less than $50 \mathrm{ml} / \mathrm{min}$ retained $60-74 \%$ of the infused aluminium; those with better renal function (creatinine clearance $>70 \mathrm{ml} / \mathrm{min}$ ) retained up to only $6.5 \%$ of the infused aluminium (table II). The figure shows the influence of deteriorating renal function on the urinary output of aluminium; the amount of aluminium removed in the "plasma bag" was only a small proportion of the input.

Plasma aluminium concentrations-Patients with a creatinine clearance of less than $50 \mathrm{ml} / \mathrm{min}$ (cases 1-4) had a tendency for their plasma aluminium concentrations after exchange to be higher than in those with adequate renal function (table III). Plasma aluminium concentration, however, did not reflect the extent of aluminium retention in any given patient.

Histomorphometry and bone aluminium content-The three patients with the poorest renal function (cases 1-3) had raised concentrations of aluminium in their bone biopsy specimens (reference value $<10 \mu \mathrm{g} / \mathrm{g}$ dry weight). In case 1 after 53 months of regular plasma exchange the patient had $38 \mu \mathrm{g}$ aluminium/g in bone and showed increased bone formation and resorption indicative of moderately severe secondary hyperparathyroidism. Bone 


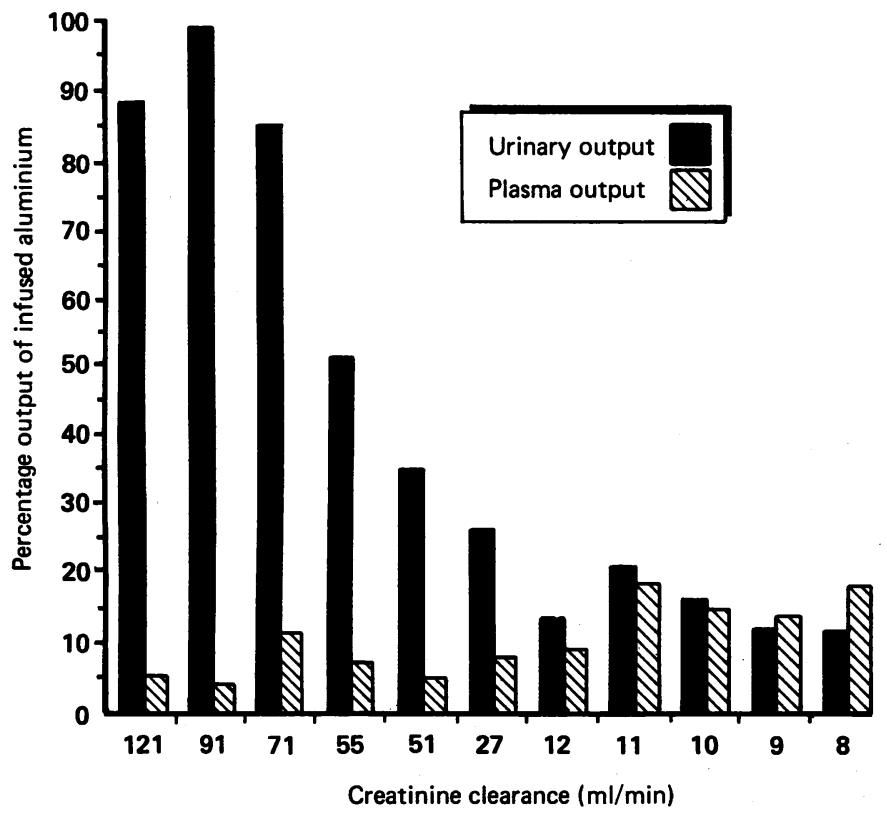

Renal function and output of infused aluminium in urine and "plasma bag." globulinaemia, all of which may be associated with severe renal impairment. Previous studies ${ }^{1-3}$ have shown that albumin solutions are contaminated to a variable extent with aluminium, which inhibits bone mineralisation and bone formation.

During experimental intravenous loading with aluminium renal clearance is extremely efficient. ${ }^{1}$ It is not thought likely that endogenous secretion of aluminium into the gastrointestinal tract is an important route of elimination, ${ }^{12}$ and faecal aluminium output mainly reflects unabsorbed dietary aluminium. We therefore excluded measurement of faecal aluminium excretion from our balance study. Of the eight patients in the series who were being treated by plasma exchange for various immunological disorders (table I), four patients with severe renal impairment retained $60-70 \%$ of the aluminium infused during plasma exchange and three patients with normal renal function retained very little (up to $6.5 \%$ of the amount infused). One patient with moderate renal impairment (creatinine clearance $55 \mathrm{ml} / \mathrm{min}$ ) retained $42-60 \%$ of the infused aluminium. A bone specimen from this patient had a normal aluminium content and no stainable aluminium.

Transiliac bone biopsy specimens from three of the patients with high aluminium retention and poor renal function showed increased bone aluminium and histologically stainable aluminium. Though none of the patients had classical aluminium related osteomalacia and the pattern of aluminium staining differed among the three, these findings can be explained on the basis of variations in bone

TABLE IV-Desferrioxamine mobilisation test

\begin{tabular}{|c|c|c|c|c|c|c|c|}
\hline \multirow{2}{*}{$\begin{array}{l}\text { Case } \\
\text { No }\end{array}$} & \multicolumn{3}{|c|}{$\begin{array}{c}\text { Plasma aluminium } \\
(\mu \mathrm{mol} / \mathrm{l})\end{array}$} & \multicolumn{3}{|c|}{$\begin{array}{l}\text { Urine aluminium } \\
(\mu \mathrm{mol} / 24 \mathrm{~h})\end{array}$} & \multirow{2}{*}{$\begin{array}{c}\text { Bone aluminium } \\
\text { - (before infusion test) } \\
(\mu \mathrm{g} / \mathrm{g})\end{array}$} \\
\hline & Before infusion & 48 Hours after infusion & Difference & Before infusion & Three days after infusion & Difference & \\
\hline $\begin{array}{l}1 \\
2 \\
3 \\
6 \\
6\end{array}$ & $\begin{array}{l}0.6 \\
1.2 \\
2.5 \\
0.1 \\
0.2\end{array}$ & $\begin{array}{r}3.0 \\
3.6 \\
14.4 \\
0.1 \\
0.2\end{array}$ & $\begin{array}{c}2 \cdot 4 \\
2 \cdot 4 \\
11 \cdot 9 \\
0 \\
0\end{array}$ & $\begin{array}{c}2.0 \\
8.4 \\
\star \\
2.4 \\
0.5\end{array}$ & $\begin{array}{r}47 \cdot 7 \\
72 \cdot 6 \\
\star \\
17 \cdot 9 \\
2 \cdot 6\end{array}$ & $\begin{array}{r}45 \cdot 7 \\
64 \cdot 2 \\
\star \\
15 \cdot 5 \\
2 \cdot 1\end{array}$ & $\begin{array}{r}38.0 \\
70 \cdot 0 \\
63 \cdot 0 \\
8.0 \\
-\end{array}$ \\
\hline
\end{tabular}

*Urine samples possibly contaminated before analysis.

mineralisation was normal and no aluminium was detected histochemically at the calcified bone-osteoid interface, though aluminium lines were present within calcified bone from previous deposition. This patient complained of intermittent bone pain. In case 2 after six months of regular plasma exchange the bone aluminium content was $70 \mu \mathrm{g} / \mathrm{g}$. The patient showed normal bone turnover, no impairment of mineralisation, and minimal deposition of aluminium at the calcified bone-osteoid interface. The third patient had been having regular plasma exchange for 84 months. His bone aluminium content was $63 \mu \mathrm{g} / \mathrm{g}$ and there was extensive deposition of aluminium at the calcified bone-osteoid interface associated with a pronounced reduction in the extent of calcification fronts indicating defective mineralisation. Osteoid seam thickness was not increased, so that appearances did not amount to frank osteomalacia. The changes of moderate secondary hyperparathyroidism were superimposed. This patient complained of intermittent bone pain. In case 5 after 27 months of plasma exchange the bone aluminium content was $8.0 \mu \mathrm{g} / \mathrm{g}$. The biopsy specimen was normal and there was no stainable aluminium.

Desferrioxamine mobilisation test-Table IV gives the results of the desferrioxamine mobilisation test in five patients. The two patients for whom we had definite evidence of aluminium retention (cases 1 and 2) showed the greatest increases in both plasma aluminium concentration and urinary aluminium excretion after desferrioxamine. The patient who showed the greatest increment in plasma aluminium concentration (case 3) had been treated for the longest time ( 84 months). (Urine samples from this patient were thought to be contaminated before analysis.) The remaining two patients (cases 5 and 6); in whom there was less aluminium retention, showed much smaller changes in plasma and urine aluminium values after desferrioxamine.

\section{Discussion}

Long term plasma exchange with albumin solutions is being used in the treatment of various conditions, including glomerular nephritis, Goodpasture's syndrome, and Waldenström's macro- turnover, the duration and frequency of plasma exchange, and thus in the total exposure of sites of bone formation to aluminium throughout the clinical history. In case 1 the patient had histological evidence of florid hyperparathyroidism in 1981 and again in the most recent bone biopsy specimen. In the interval, however (after treatment with $1 \alpha$-hydroxyvitamin $D$ ), she was biochemically euparathyroid for several years, and the aluminium lines within calcified bone were thought to represent heavy deposition of the metal at the calcified bone-osteoid interface during the euparathyroid phase. This patient complained of intermittent bone pain.

The skeleton of the patient in case 2, who had normal bone turnover, had not been exposed to aluminium for long enough to cause severe osteodystrophy, though there was a build up of aluminium in bone. The patient in case 3, with milder hyperparathyroidism than in case 1 , showed a "mixed" bone disease, having a sufficiently low bone turnover to allow accumulation of aluminium at the calcified bone-osteoid interface, yet with enough turnover to offer a large osteoid surface for uptake of aluminium and produce defective mineralisation but not frank osteomalacia. This patient also complained of intermittent bone pain.

Plasma aluminium concentrations measured before and after exchange were not an accurate index of aluminium retention, though there was a tendency for the patients with poor renal function to have the highest plasma aluminium concentrations immediately after exchange. Concentrations, however, did not exceed $3.7 \mu \mathrm{mol} / 1$, which was suggested by Charhon et al as the value at which aluminium deposition in bone was probable in patients having haemodialysis. ${ }^{13}$ We have shown that aluminium retention may be present at plasma aluminium concentrations well below $3 \cdot 7 \mu \mathrm{mol} / 1$.

One patient whose balance studies showed some retention of aluminium (case 5) was similar to the case reported by Milliner et al; 
they found no bone biopsy evidence of aluminium toxicity in a patient with a normal serum creatinine concentration who had received a total of 83 plasma exchanges with albumin solutions contaminated with aluminium. ${ }^{14} \mathrm{We}$ do not agree, however, that the amount of aluminium delivered in infusions of albumin is too small to present a real risk. ${ }^{15}$ Detecting aluminium retention requires metabolic balance studies and bone biopsy and cannot be based on plasma aluminium concentrations alone.

As none of our patients was being treated by haemodialysis and only one (case 1) was receiving aluminium hydroxide as a phosphate binder (the two usual sources of aluminium in chronic renal failure), we conclude that the accumulation of aluminium in bone was a result of infusing albumin contaminated with aluminium.

Though aluminium induced osteomalacia is the best described effect of chronic aluminium toxicity, neurotoxicity is also well recognised ${ }^{7}$ and there is interest in the role of aluminium in Alzheimer's disease and other degenerative conditions related to aging. ${ }^{16} 17$

Patients given infusions of contaminated albumin are receiving up to $\mathbf{1 0 0}$ times the amount of aluminium normally absorbed from the diet. Given the potential toxicity of aluminium, doctors should avoid the prolonged administration of large volumes of albumin (or other products contaminated with aluminium) to patients with renal impairment.

We thank Dr C Brown, of the Royal Hallamshire Hospital, Sheffield, for allowing us to study a patient under his care and Mrs A McKenna for the aluminium analyses.

\section{References}

1 Fell GS, Shenkin A, Halls DJ. Aluminium contamination of intravenous pharmaceuticals, nutrients, and blood products. Lancet 1986;i:380.

2 Fell GS, Maharaj D. Trace metal contamination of albumin solutions used for plasma exchange. Lancet 1986;ii:467-8.

3 Maher ER, Brown EA, Curtis JR, Phillips ME, Sampson B. Accumulation of aluminium in chronic renal failure due to administration of albumin replacement solutions. $\mathrm{Br} \mathrm{Med} \mathcal{J}$ 1986;292:306.

4 Urbaniak SJ. Replacement fluids in plasma exchange. Apheresis Bulletin 1983;1(2):104-13.

McGinlay E, Mclay A, Boulton-Jones JM. Plasma exchange in the treatment of mesangiocapillary glomerulonephritis. Nephron 1985;40:385-90.

6 Boyce BF, Fell GS, Elder H, et al. Hypercalcaemic osteomalacia due to aluminium toxicity. Lance 1982;ii:1009-12.

7 Willis MR, Savory JA. Aluminium poisoning: dialysis encephalopathy, osteomalacia, and anaemia. Lancet 1983;ii:29-33.

8 Malluche HH, Smith AJ, Abreo K, Faugere MC. The use of desferrioxamine in the management of aluminium accumulation in bone in patients with renal failure. N Englf Med 1984;311:140-4.

9 Gardiner PE, Ottaway JM, Fell GS, Halls DJ. Determination of aluminium in blood plasma or serum by electrothermal atomic absorption spectrometry. Analytica Chimica Acta 1981;128. $57-66$

10 Halls DJ, Fell GS. Determination of aluminium in dialysate fluids by atomic absorption spectrophotometry with electrothermal atomisation. Analyst 1985;110:243-6.

1 Kovalchik MT, Kaeheny MT, Jackson T, Alfrey AC. Aluminium kinetics during hemodialysis. f Lab Clin Med 1978;92:712-6.

12 Alfrey AC. Aluminium. Adv Clin Chem 1983;23:69-91.

13 Charhon AS, Chavassieux PM, Meunier PJ. Serum aluminium concentration and aluminium deposits in bone in patients receiving haemodialysis. Br Med J 1985;290:1613-4.

14 Milliner DS, Shinaberger JH, Shuman P, Coburn JW. Inadvertent aluminium administration during plasma exchange due to aluminium contamination of albumin replacement solutions. N Engl f Med 1985;312:165-7.

15 Davenport A, Roberts NB. Serum aluminium levels in acute renal failure. Lancet 1986;ii:1397-8.

16 Candy JM, Oakely AE, Klinowski J, et al. Aluminosilicates and senile plaque formation in Alzheimer's disease. Lancet 1986; i:354-6.

17 Ganrot PO. Metabolism and possible health effects of aluminium. Environ Health Perspect 1986;65:362-411

(Accepted 31 fuly 1987)

\section{SHORT REPORTS}

\section{Anterior ischaemic optic neuropathy in the acquired immune deficiency syndrome}

Anterior ischaemic optic neuropathy ${ }^{1}$ is most common in elderly patients with temporal arteritis but may also occur in younger patients after acute hypotension or as a complication of hypertension, diabetes, or autoimmune disease. We report on a middle aged man in whom anterior ischaemic optic neuropathy was the presenting symptom of the acquired immune deficiency syndrome (AIDS).

\section{Case report}

A 45 year old white man presented in February 1986 with sudden onset of blurred vision in his right eye, deteriorating memory over the previous two years, and mild intermittent frontal headaches over the previous six months. He had worked in Zambia during 1970-3 and 1979-84 and had been sexually promiscuous, contracting gonorrhoea, non-specific urethritis, and genital herpes. He had not indulged in homosexual activity but had received a blood transfusion in 1980 while in Zambia.

Visual acuity was 6/36 in his right eye, which had a pale and swollen optic disc, especially over the upper half, with small haemorrhages on its surface. His right visual field showed an inferior altitudinal defect. He had several discrete lymph nodes in his groin, left axilla, and left posterior cervical triangle. His liver was slightly enlarged but not tender. Blood pressure and heart sounds were normal, and there were no carotid bruits. Formal psychometric testing confirmed mild impairment of verbal recall and immediate memory span with more severe impairment of his memory for words and faces.

Anterior ischaemic optic neuropathy was diagnosed clinically and confirmed by fluorescein angiography, which also showed delayed filling of the choroidal circulation in the upper nasal quadrant that was still evident in the early to middle retinal venous phase. When choroidal filling was complete the disc began to leak fluorescein, increasingly so in the late phase. The figure shows fluorescein staining of the wall of two short sections of the inferior temporal retinal vein, near the disc margin and just nasal and inferior to the fovea. His retinal circulation was otherwise normal.

Erythrocyte sedimentation rate was raised at $38 \mathrm{~mm}$ in the first hour, but routine haematological and biochemical variables (including blood glucose concentration) were otherwise normal. Fasting cholesterol and triglyceride concentrations were normal. Serological tests for syphilis, hepatitis B surface antigen, and autoantibodies yielded negative results, but the serum titre of antibodies to human immunodeficiency virus was raised at 1/4000. Computed tomography of the brain showed nothing abnormal. Analysis of cerebrospinal fluid showed a normal cell count and total protein concentration and a high antibody titre to human immunodeficiency virus. Lymphocyte surface markers showed the characteristic features of infection with human immunodeficiency virus with selective reduction in numbers and percentage of T4 cells. Tests for toxoplasma and cytomegalovirus were negative.

Fluorescein angiography four months later showed complete resolution of al the changes. At his last ocular examination 10 months after the onset visual acuity was $6 / 18$ and the upper half of the disc was atrophic. The inferior altitudinal visual field defect had not changed.

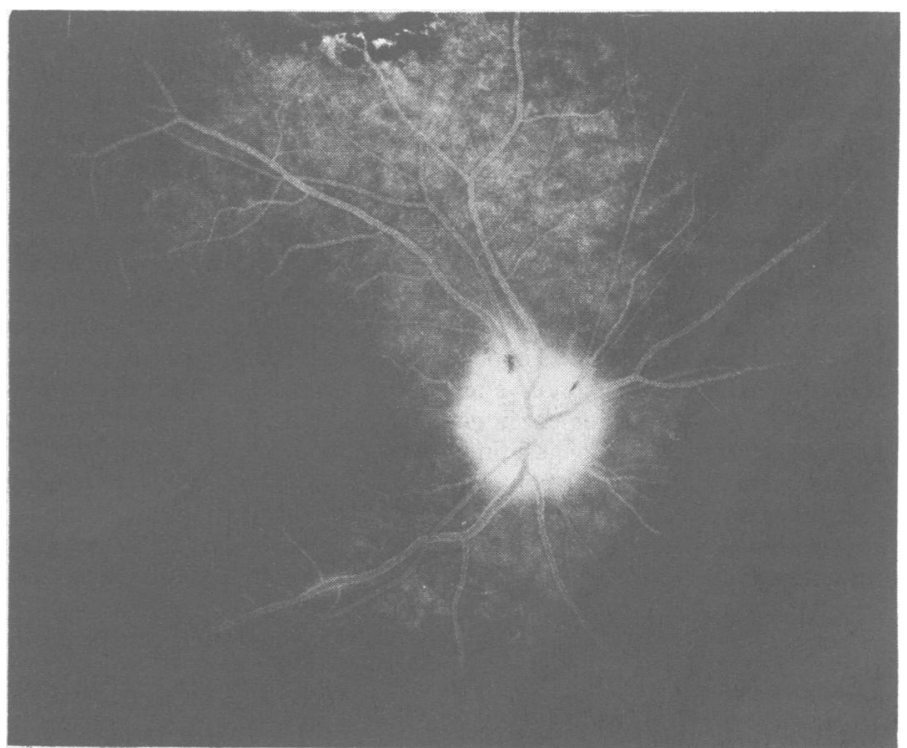

Fluorescein angiogram showing swollen disc with hacmorrhages and staining of two sections of inferior temporal retinal vein. 